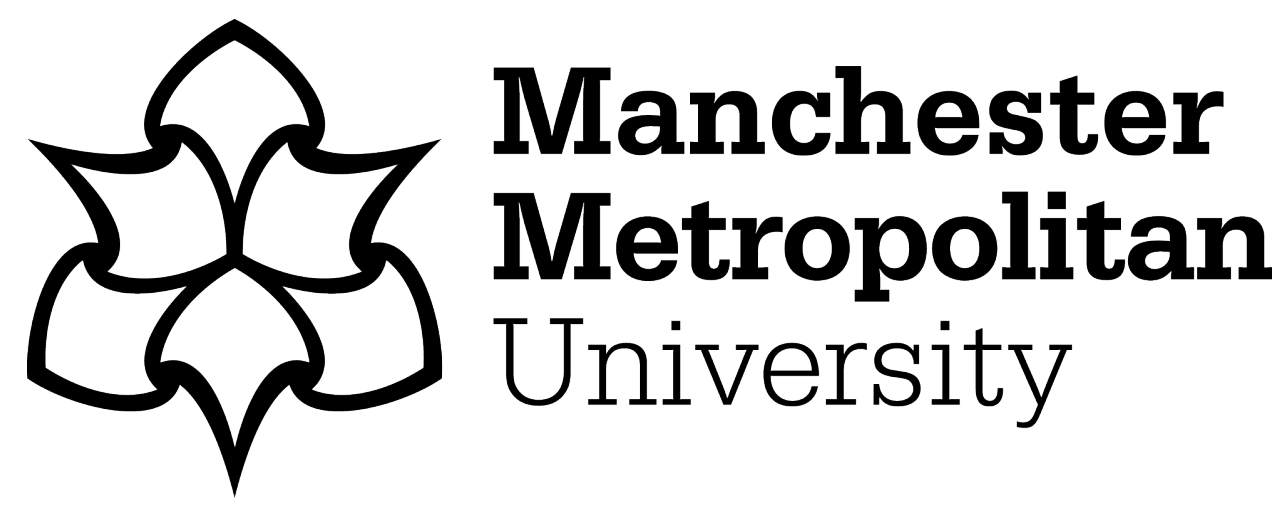

Huysamen, Monique ORCID logoORCID: https://orcid.org/0000-0002-5664998X, Barnett, Julie and Fraser, Danae Stanton (2020) Slums of hope: Sanitising silences within township tour reviews. Geoforum, 110. pp. 87-96. ISSN 0016-7185

Downloaded from: https://e-space.mmu.ac.uk/625160/

Version: Accepted Version

Publisher: Elsevier BV

DOI: https://doi.org/10.1016/j.geoforum.2020.01.006

Please cite the published version 


\section{Slums of hope: Sanitising silences within township tour reviews}

Monique Huysamen, Julie Barnett, and Danae Stanton Fraser

Department of Psychology, University of Bath, UK

Declarations of interest: none

Accepted 12 Jan 2020

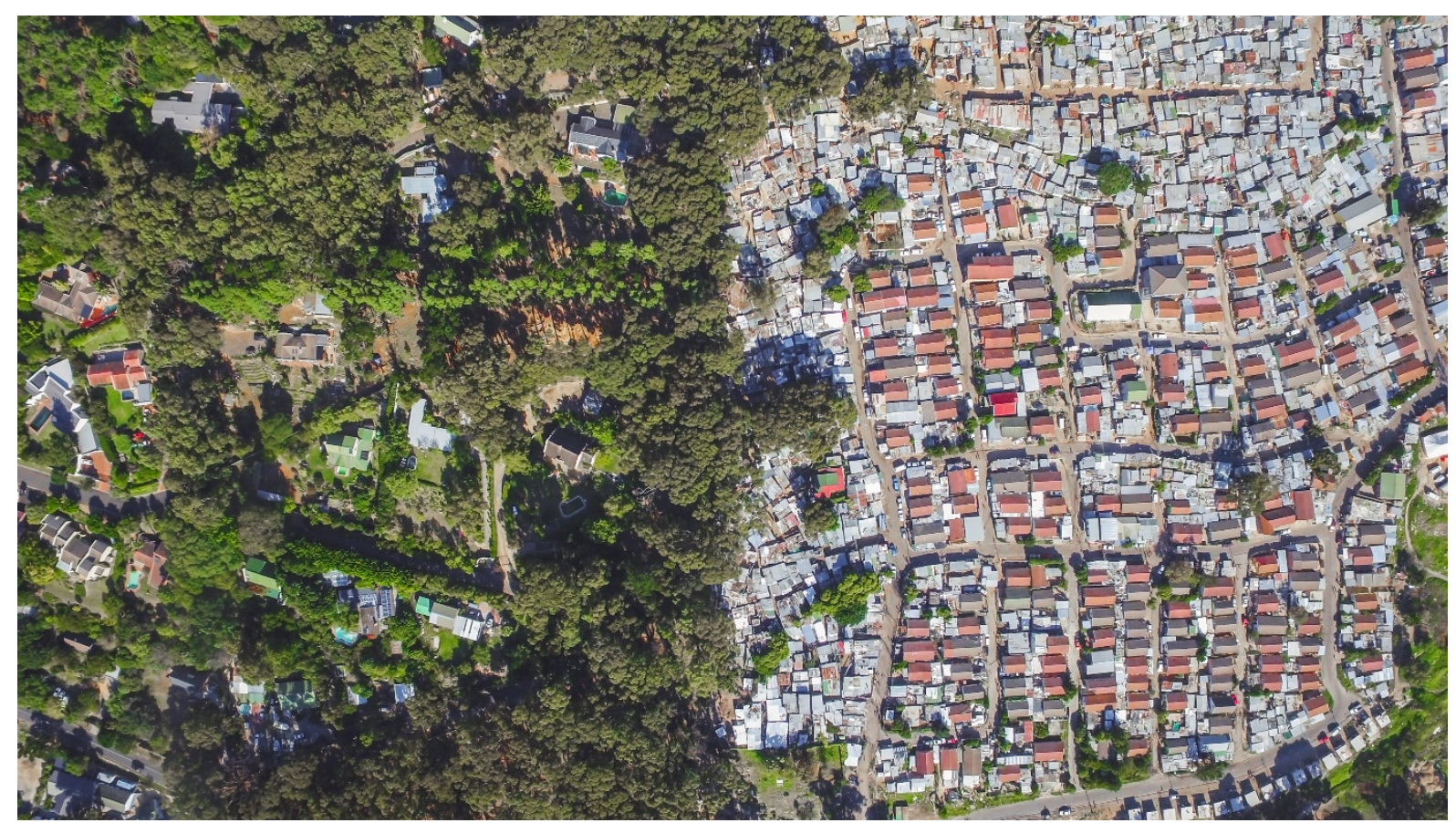

Image: Imizamo Yethu Township, Hout Bay. By Johnny Miller, Unequal Scenes Project 


\section{Slums of hope: Sanitising silences within township tour reviews}

In a context of rapidly increasing urbanisation and deepening global inequalities, slum tourism has thrived. This paper presents a discursive analysis of tourists' online reviews of two township tours in Cape Town, South Africa. We investigate how, and to what ends, tourists collectively construct townships as places of hope on TripAdvisor; we question how these reviews feed into broader narratives of urban poverty in the global south. We show how tourists draw on both neoliberal and colonial discourses to construct townships as places of hope-vibrant cultural spaces, rich in non-material assets, inhabited by happy, hard-working residents. We show that by producing slums as productive cultural spaces, tourists are able to resist the stigma associated with slum tourism and position themselves as ethical, enlightened and morally superior tourists. We argue that neoliberal and colonial discourses operate together to produce sanitised representations of townships that both obscure inequalities between poor residents and wealthy tourists from the global north and depoliticise issues like poor infrastructure in townships. In discussing the broader implications of the study, we highlight the importance of producing nuanced representations of townships that acknowledge residents' assets and excellence, while also foregrounding how they live within the oppressive constraints inherent in enduring systems of inequality.

\section{Urban poverty; townships; slum tourism; South Africa; discourse analysis; online research}

\section{Introduction}

In a context of rapidly increasing urbanisation and deepening global inequalities, slum tourism has thrived. While modern slum tourism began in 1991, in South Africa, the practice of gazing at the poor is much older (Frenzel, 2016; Koven, 2006). Steinbrink (2012) traces the practice of slumming back to nineteenth century England, when wealthy Londoners, motivated by curiosity or charitable, academic, or political intentions, visited the slums of London's East End (Frenzel, 2016; Steinbrink, 2012). This paper presents a discursive analysis of tourists' TripAdvisor reviews of two township tours in Cape Town.

This paper contributes to a limited body of work which explores how ideas about poverty in the global south are discursively produced and collectively disseminated on TripAdvisor 
(Iqani, 2016). We will demonstrate how tourists draw on both neoliberal and colonial understandings of poverty in the global south to produce townships as places of hope. We will argue that constructing townships as places of hope-vibrant, productive cultural hubsallows tourists to both resist the stigma associated with slum tourism and position themselves as ethical, enlightened, and morally superior tourists. In the section that follows, we present a brief review of relevant academic debates and research surrounding slums and the practice of slum tourism.

\section{Review of the literature}

\subsection{The slum: Definitions and dominant discourses}

Any attempt to define the term 'slum' can ultimately be contested on the grounds that it belies the complexity of the phenomenon and its blurred boundaries (quite apart from the fact that definitions are always social constructs not reflections of reality). (Nuissl and Heinrichs, 2013: 107).

Slums, or townships as they are known in South Africa, are diverse, complex, multifaceted, and constantly-evolving urban spaces that cannot be adequately represented by a single definition (Nuissl and Heinrichs, 2013; Owusu et al., 2008; Rolfes, 2010). However, slums tend to be characterised by severe urban infrastructural deficits and poor living conditions. We draw on a broad definition of slums as 'areas of relative urban poverty' (Frenzel, 2016: 10). Nuissl and Heinrichs (2013) provide a detailed outline of the various ways that slums and their residents have been defined and conceptualised by academics and by policy makers. The 'slums of hope' and 'slums of despair' ${ }^{1}$ dichotomy reflects two of the most dominant discourses in academic debates on slums (Nuissl and Heinrichs, 2013). Each of these two competing discourses is associated with a set of assumptions about the nature of the slum; each produces different subject positions for slum residents; and each implies a different set of assumptions about how the phenomena can or should be addressed within society. The slums of despair discourse, often said to be exemplified by the work of Davies (2006), pessimistically positions slums as places of stagnation characterised by economic and social exclusion, and as inherently devoid of opportunities for substantial economic development

\footnotetext{
${ }^{1}$ These terms were first introduced in academic writing on slums by Stokes (1962).
} 
and social mobility for residents. The slums of hope discourse, on the other hand, centres on the productive potential of the slum. It foregrounds the resources within slums and highlights the resilience and industriousness of residents. This optimistic discourse of self-help and resilience reproduces broader neoliberal market-orientated principles of governance centring on reduced state responsibility for the poor (Bansel, 2007; Reed, 2012). The slums of hope discourse, we argue, produces the ideal neoliberal subject who is adaptive, self-sustaining, and able to help themselves out of poverty through hard work, entrepreneurism, good choices, and by making the most of the resources that are available to them.

\subsection{Slum tourism: ethical debates}

Slum tourism is a loaded, contentious, and much-debated issue within both the public and academic domains. This debate must be located within the broader context of a growing awareness globally about the potential negative effects of mass tourism, and an increasingly dominant moralising 'anti-tourist' discourse that constructs mass tourism as gratuitous and crass (Burgold and Rolfes, 2013; Jovicic, 2016; Mahrouse, 2011; Welk, 2004). Slum tourism is often framed as particularly morally questionable and as an unethical form of voyeurism linked to coloniality (Freire-Medeiros, 2009; Iqani, 2016). Slum tourists are criticised by academics and within the media for supporting the commoditisation, romanticisation, and consumption of poverty, and are accused of engaging in 'poverty tourism' or a form of 'poverty porn'2 (Freire-Medeiros, 2009; Iqani, 2016). Traveling freely and for leisure, particularly across international borders, is premised upon relative material wealth, a privilege of the global middle class (Iqani, 2016). It is thus unsurprising that to travel to the global south to gaze at a slum, a place defined by poverty, provokes moral anxiety and outrage (Freire-Medeiros, 2009; Frenzel, 2016).

However, strong counter-discourses to those of immorality and exploitation exist. Research shows that both slum tourists and slum tour companies deploy discourses 'ethical' tourism to reframe slum tourism as a moral and ethical practice (Burgold and Rolfes, 2013; Butler, 2010; Iqani, 2016). So called 'ethical' and 'alternative' tourism practices such as ecotourism and voluntourism, along with other practices like backpacking, are premised on offering socially

\footnotetext{
${ }^{2}$ See Feltwell et al.'s (2017) research on social media discussions around poverty porn.
} 
responsible alternatives to traditional mass tourism for tourists from the global north (see Huggan, 2002; Jovicic, 2016; Mahrouse, 2011; McWha et al., 2016; Welk, 2004). Ethical tourism is constructed as providing non-intrusive, authentic encounters that function to conscientise tourists about poverty and inequality and contribute to the sustainable development of low-income communities (see Mahrouse, 2011). These ethical tourism discourses produce a specific moral and ideological position for the tourist as someone who is motivated by desire to help, learn, and understand rather than purely by self-interest (Iqani, 2016).

Burgold and Rolfes (2013), drawing on Butcher's (2003) concept of New Moral Tourism, show how tourists visiting slums in Cape Town and Mumbai reproduce these discourses of ethical tourism to reframe the slum tours they engaged in as ethical rather than exploitative. Similarly, Iqani (2016) in her discursive analysis of TripAdvisor reviews of slums tours in Cape Town, Mumbai, and Rio de Janeiro, shows how the moral subjectivity of the tourist is centred in TripAdvisor reviews to produce the moral and enlightened tourist. Tourists across all of these studies described township tours as a form of ethical consumption, as educational, humbling, and as an enlightening experience (Burgold and Rolfes, 2013; Iqani, 2016). They constructed the tours as opportunity to see the 'real' or authentic South Africa or India. Slum tourists, like tourists engaging in 'ethical' or 'alternative' forms of tourism (Jovicic, 2016; Mahrouse, 2011; Welk, 2004), defined themselves as having greater moral integrity than tourists who chose to ignore poverty rather than be educated about it.

\subsection{Slum tourism: shifting representations of the slum}

We situate our analysis of slum tourism at the level of the discursive and representational. We follow Iqani (2016: 83) in conceptualising the phenomenon of slum tourism as 'socially constructed and produced by the actors who create, offer, consume and reflect on slum tours'. Research by Freire-Medeiros (2009), Frenzel (2016) and Williams (2008) highlights how slum tourism is not merely a passive social phenomenon but a productive one; when tour companies represent slums to tourists in specific ways, slum tours are 'spoken into being' as particular discursive objects (Iqani, 2016: 84). Similarly, tourists do not passively gaze at or consume slums, but play an active role in producing the slums discursively through their accounts of going on the tours (Freire-Medeiros, 2009; Iqani, 2016; Williams, 2008). 
Empirical research supports the assertion that slum tourism can play a role in shifting the ways that slums and poverty are discursively represented by tourists (Meschkank, 2011; Rolfes, 2010). Rolfes (2010) and Meschkank (2011) conducted empirical case studies of slum tours in Cape Town and Dharavi respectively to explore tourists' accounts of slums and poverty before and after they embarked on the tours. Both studies showed a marked shift in the poverty semantics participants used from 'slums of despair' discourse before the tour to 'slums of hope' discourse after the tour. Before the tours, tourists gave descriptions of slums centring on passivity, crime, poor education, poor hygiene, poor sanitation infrastructure, laziness and stagnation. After the tours, tourists' descriptions centred on activity, progress, the friendliness of the people, the sense of community, and good educational opportunities. In this paper, we will explore how the accounts collectively produced by slum tourists on TripAdvisor may reproduce, reinforce, or shift dominant global understandings and representations of slums and the urban poor.

\subsection{Slum tours and TripAdvisor}

Iqani (2016) and Nisbett (2017) contribute to the body of critical research on slum tourism by focusing their analysis on an area that has had comparably less attention in slum tourism scholarship to date: the mediation of tour experiences by tourists' TripAdvisor reviews (Iqani, 2016). TripAdvisor is a user-generated tourism advice website that markets itself as the world's largest travel platform. TripAdvisor is continuously updated by its users and therefore represents 'a living and evolving collectively produced discourse about tourism' (Iqani, 2016: 66). Both Iqani (2016) and Nisbett (2017) conducted in-depth qualitative analyses of TripAdvisor reviews. While Iqani analysed reviews of tours of Dharavi, Santa Marta and Langa, Nisbett focused only on reviews of tours of Dharavi. In agreement with other research on tourists' accounts of slum tours (Meschkank, 2011; Rolfes, 2010), both studies found that 'slums of hope' discourse dominated tourists' post-tour reviews. However, both researchers problematise the optimistic neoliberal understandings of poverty underpinning tourists' reviews. Contrary to research that suggests that slum tourism can have a strong conscientising effects (Diekmann and Hannam, 2012; Dyson, 2012) and can lead to material changes (Frenzel, 2016), Iqani and Nisbett argue that these neoliberal scripts serve to depoliticise and naturalise poverty and inequality. Nisbett (2017) notes that that, while slums 
of hope discourses dominated reviews, poor sanitation, lack of clean water, and squalid living conditions remained almost completely unacknowledged in tourists' TripAdvisor reviews, concealing the need for urgent structural change. Iqani (2016: 74) argues that tourists' narratives about being 'humbled' by witnessing poverty reflects a colonial gaze that discursively fixes slums outside urban modernity while narratives of hard-working, dignified, proud, and happy residents minimises 'the violence of poverty' and erases the longestablished structural inequalities and injustices that have produced these relative positions of poverty and privilege in the first place.

We contribute to this limited body of work that explores how ideas about township tours are collectively produced on TripAdvisor reviews (Iqani, 2016). Specifically we employ a discursive approach to analysing tourists' reviews of tours of two townships in Cape Town, Langa and Imizamo Yethu. Before outlining our research methodology, we provide a brief introduction to these two townships.

\section{The research context: Langa and Imizamo Yethu}

Langa is the oldest surviving township in Cape Town. It was established in 1927 in accordance with Native Urban Areas Act of 1923. Langa is densely populated, with approximately 52,000 people living in an area of 3.09 square kilometres (De Satgé and Watson, 2018). Today, Langa is comprised of both formal and informal housing, including shacks that lack basic water and sanitation infrastructure, overcrowded dormitory accommodation with communal ablution blocks originally designed for single migrant labourers, as well as flats and freestanding houses (De Satgé and Watson, 2018).

Imizamo Yethu is located on the outskirts of Hout Bay, an affluent coastal suburb about 20 kilometres from Cape Town city centre. Imizamo Yethu was established in 1991 to accommodate black South Africans working in the fishing industry and as domestic workers in the affluent surrounding areas (Kahanji et al., 2019). Imizamo Yethu is a smaller township, with a total area of about 0.57 square kilometres and a population of 15,538 people according to the 2011 census; however, the current population estimates for this ever-growing settlement are far higher (Gibson et al., 2019). Imizamo Yethu is notorious for its lack of basic services and sanitation infrastructure. The settlement has a ratio of one toilet to eleven 
households, and the vast majority of residents live in informal housing (Gibson et al., 2019; Kahanji et al., 2019).

\section{Methods}

\subsection{Theoretical Framework}

This research is informed by critical discursive and decolonial approaches to language and power. Decolonial theory examines how the dehumanised black Other was manufactured through the process of colonisation, and attends to the ways in which these colonial representations of the Other continue to be produced and reproduced in contemporary society (see Boonzaier, 2017; Huysamen and Boonzaier, 2018; Lugones, 2010).

We employed a critical/Foucauldian discourse analysis (Parker, 1992, 2004) to examine the ways in which language is deployed to construct particular objects and subjects, and how these are relational and invested with power (Boonzaier, 2017). Discourses can be defined as different systems of meaning for understanding, experiencing, and acting in the world (Parker, 2004). Discourses stipulate how ideas about a particular issue (for example, poverty or tourism) are put into practice, and establish rules that restrict alternative ways of knowing, talking about, or conducting ourselves in relation to these issues within a particular sociohistorical context (Parker, 1992, 2004). From this critical discursive perspective, we do not read tourists' reviews as mirrors of reality that offer factual accounts of the townships, but rather we understand the meaning of these townships as constructed through language (Parker, 1992; Wetherell, 2007). To this end, the object of our study is not the township tours themselves, but the language that tourists use in their reviews on TripAdvisor.

From this discursive perspective, we understand language as inherently social, as always produced in relation to, or in conversation with, others, real or imagined (Wetherell, 2007). We draw on Walker et al.'s (2010: 932) work on the imagined public which suggests that (in the context of policy-making) 'an imagined, anticipated public is produced, given voice, and assigned a presumed subjectivity. This imagined public thus becomes an actor with agency and political significance, available to be invoked'. We understand TripAdvisor reviews to be collectively produced for, or in conversation with, an imagined tourist. The imagined tourist 
is a like-minded tourist from the global north who has the means and inclination for travel to destinations like South Africa.

\subsection{Data collection and data analysis}

Tour selection. There are numerous township tour operators in Cape Town with profiles on TripAdvisor, we therefore had to make some decisions about which tours to select. We chose tours of two townships, Imizamo Yethu and Langa, each offered by a different tour operator. The Langa township tour company is locally owned and run, and is one of the most popular and regularly reviewed tours on TripAdvisor. The Imizamo Yethu tour is a smaller community run tour offered as an optional stop along a hop-on-hop-off city sightseeing tour bus route.

Ethnographic encounters. In order to contextualise our analysis, the first author went on both of the township tours once. She participated in the tours as any other tourist would, but observed carefully the kinds of places in the townships that tourists were shown by the guide, the information they were provided, and the kinds of questions other tourists asked. Directly after each tour she made detailed field notes and wrote reflections in a research journal.

Data Collection. We manually scraped the TripAdvisor website for all reviews pertaining to the two selected tours (452 reviews in total) and transferred them to word processor documents. We excluded any reviews that were not published in English. The volume of reviews differed between the two tours. While there were 35 English reviews for the tour of Imizamo Yethu, there were 417 reviews of the Langa tour at the time of data collection in March 2019.

Data analysis. We then selected the latest 35 reviews of each of the two tours and subjected them to a rigorous thematic discursive analysis. We identified the discursive patterns of meaning across these 70 reviews by employing an approach to discourse analysis that could be defined as a 'sensitivity to language rather than as a 'method"' (Parker, 2004: 310). This fluid analytic process involves identifying common themes and subthemes and returning to, re-organising, and refining these themes repeatedly to identify 'underlying systems of meaning' (Taylor and Ussher, 2001: 297). While it is common to enlist software to analyse large online data sets (see Colditz et al., 2018; Privitera, 2015), our discursive analysis requires commitment to attending closely to the, often implicit, ways in which language and power 
operate in the context of the broader text. We, like Braun and Clarke (Braun et al., 2019; Braun and Clarke, 2006) choose to analyse qualitative data thematically without the use of computer-assisted software.

Once the themes and sub-themes had been identified within the 70 reviews, we compiled a list of keywords within the semantic fields of each of the themes. We then searched across all 452 reviews for each of these terms. Each review containing any of our search terms was then subjected to the same close discursive analysis outlined above. This allowed us to explore how the discursive themes we identified in our smaller sample manifested throughout the rest of the reviews. The final themes and subthemes which we identified are presented in the discussion of the findings that follows. The poststructuralist paradigm that underpins the study welcomes plurality of meaning, and we see our analysis as subjective, and as just one of many possible readings of the data (Huysamen, 2019).

Ethical considerations. TripAdvisor users post reviews in the public domain intended for a wide public audience under pseudonyms or nicknames. We assigned new pseudonyms to add another layer of anonymity. The study was granted ethical approval from the Psychology Research Ethics Committee at the University of Bath.

\section{Discussion of the findings}

In line with previous research, narratives about the townships as places of hope and progress reverberated across almost all of the tourists' reviews (Burgold and Rolfes, 2013; Iqani, 2016; Nisbett, 2017). In this paper, we explore how, and to what ends, tourists collectively constructed townships as places of hope on TripAdvisor. We present the discussion of our findings in two sections. In the first section we attend to the how question, discussing the discursive mechanisms employed by tourists to construct townships as places of hope on TripAdvisor. In the second section, we examine what the function of producing slums as places of hope might be for tourists. We will argue that tourists, drawing on colonial and neoliberal discourses, constructed townships as places of hope to allow them to reframe township tours as a form of ethical tourism. 


\subsection{The collective production of 'slums of hope' on TripAdvisor}

The absence of despair. It is important that we first situate these discourses of hope as produced within the absence of discourses of despair. Our analysis revealed that the most striking feature of the reviews was, in fact, the absences and silences within them. Out of all the reviews we analysed, we found only one (a review of Imizamo Yethu) that described residents as dispossessed and living in abject poverty. This one review emphasised social inequality, the South African government's failure to provide for residents, and described the poor housing facilities, high prevalence of disease, and lack of basic water and sanitation infrastructure characteristic of Imizamo Yethu. Apart from this review, TripAdvisor reviews were devoid of more pessimistic 'slums of despair' discourse (see Davis, 2006). Townships were produced as places of hope primarily in the absence of discourses of despair.

We specifically noted a marked absence of discourses on health, disease, water and sanitation. Across 452 TripAdvisor reviews, only four reviews remarked on water, sanitation, or sewerage within townships whatsoever. Only two of these communicated the fact that the majority of residents in these settlements live without toilets or running water inside their homes. The lack of sanitation infrastructure in townships across Cape Town have been deeply politicised over the past decade, with the state's failure to provide adequate sanitation infrastructure in townships resulting in protest and much media attention (See McFarlane and Silver, 2017; Robins, 2014a, 2014b). Consistent with Nisbett's (2017) analysis of TripAdvisor reviews, our analysis clearly shows how the material conditions of poverty and social inequality, particularly those centring around health and sanitation, were largely silenced within TripAdvisor reviews. These silences provide important insights into how townships and urban poverty come to be discursively produced on TripAdvisor. In the remainder of this section we discuss four other ways in which reviewers collectively produced townships as places of hope: by constructing them as 'rich' in non-material assets, through employing discourses of self-improvement, through producing the image of the poor but happy child, and through employing discourses of choice. We show how both neoliberal and colonial understandings are deployed together to produce townships as places of hope.

The 'rich' community. Tourists commonly produced townships as places of hope by foregrounding residents' non-material strengths and assets, sometimes with little or no reference to any deficits or deprivation. 
Our guide was particularly wonderful and it was clear that he was proud of where he came from and shared so many rich experiences with us... You really get a feel for the sense of community and fellowship that still prevails in these areas. (Imizamo Yethu: James, Singapore)

We had a fabulous walking tour of the Langa Township - like others, we had wondered if this would be voyeuristic, but it actually wasn't. We learned so much, and it was wonderful to be in the community, to experience the friendship, the solidarity - to see a new future being built. (Langa: Pam_Tom, UK)

Drawing on understandings of non-western societies as collectivist, tourists highlighted the 'sense of community' within the townships: terms such as 'community', 'fellowship', 'friendship', 'solidarity', 'belonging' and 'togetherness' were all prevalent in the data. Tourists also highlighted other assets like the positive energy, sense of pride, and love that people in the townships possessed. As Iqani (2016) posits, these narratives of spiritual wealth in the context of material poverty position the township residents as Other, reproducing colonial imagery of the 'noble savage' not yet corrupted by civilisation. Tourists often directly compared townships to their own societies in the global north, which they constructed as deficient in these non-material assets, morals and traditional values. Here we see how the position of the rich tourist from the global north and the poor slum dweller from the global south are flipped, obscuring the relationship of inequality that has always and continues to exists between the two (Iqani, 2016).

Discourses of self-improvement. While some reviews were devoid of descriptions of the material conditions and deficits in the townships, others tourists did talk of the 'poverty' that they witnessed. Our analysis revealed that the word poverty was consistently juxtaposed with, and reframed by, narratives of hope and progress. The examples below demonstrate how the word 'hope' was consistently used alongside the word 'poverty' as a reframing device:

Despite the poverty we could also see hope and development (Langa: Stefan, unknown)

This might be a little upsetting but everyone should visit. The level of poverty that these people live in is unbelievable. But everyone here has hope and aspirations of getting a house and work. Truly amazing people. (Imizamo Yethu: Norman, UK) 
Norman's review above demonstrates that reframing poverty in terms of hope is an important device for mitigating or buffering the 'upsetting' feelings that the township tourist might experience as a result of engaging with poverty and inequality while in the townships. Frenzel argues that slum tourism is an important social practice to study because it reflects 'an interest, perhaps an unease, about poverty among those who are better off' (Frenzel, 2016: 4). Our analysis highlights how slums of hope discourses, steeped in both neoliberal market and colonial constructions of the poor, are employed by tourists in order to ease these feeling of unease.

Neoliberal discourse that position residents as working hard to improve their own lives were prominent in reviews:

We felt totally safe with the guide and were welcomed by the people who, despite living in shocking conditions, are trying hard to improve their lives... It is a totally different experience from the rest of the Cape Town sights, and although upsetting, is uplifting at the same time to see people trying to make the best of their lives. (Imizamo Yethu: Jack22, UK)

Proud community trying to build a better life (Imizamo Yethu: Nico20, USA)

There are hardworking people in the township who are making life better for themselves. (Langa: Alex, USA)

While tourists recognised the 'shocking conditions' of the townships, they positioned residents within the neoliberal discourse of self-improvement. Residents were constructed as good neoliberal subjects (Rutherford, 2018) who, through hard work, could lift themselves out of poverty. Rather than foregrounding that residents live in conditions of abject poverty, operating within a structural system of perpetual disempowerment as part of the continuing effects of South Africa's long history of colonisation and apartheid, these neoliberal discourses positioned residents in a transient state of poverty, one that they can, and are, moving themselves out of.

Some tourists provided physical evidence of the progress and improvement that had already occurred in the townships. In these narratives, the community's resources and facilities such as schools, community centres, businesses, and sports fields were highlighted. Some reviews were littered with misperceptions and misinformation, particularly around the structure and status of the housing within the townships. 
It was good to see that the township has developed and that more and more proper homes are built there. Luckily there are now only few sheds left - the remaining ones seemed open for tourists. People seemed happy, especially the children were a joy to watch. We felt very safe - no issues at all. (Langa: EuroTraveller, Denmark)

\section{Disappointing tour of Langa Township:}

Most of Langa township has been bulldozered down and rebuild with new houses or renovated houses. Only the in last part of the tour you could experience the live as it use to be people living in severe circumstances but this part will be rebuild from beginning of 2015. Government is doing a good job creating better circumstances for the people living in Langa. If this is finished I would recommend to visit other townships to get a better idea how tough life is living in a township. (Lanaga: Johan, Netherlands)

Noteworthy here is EuroTraveller's understanding of the shacks in the townships being 'for tourists', and Johan's disappointment at not finding more people living informal shack housing during his tour. Contrary to both of their assumptions, shacks are not simply 'for tourists' and most residents of Langa do not live in 'new or renovated houses'. While new brick housing has been built as part of the South African government's Gateway housing project (see De Satgé and Watson, 2018), thousands of residents live in informal shacks or dilapidated overcrowded concrete dormitory accommodation originally built for single black male migrant labourers. Rather than evidence of progress, these structures represent the architecture of colonialism and apartheid. While some research points to the conscientising potential of slum tours (Diekmann and Hannam, 2012; Dyson, 2012) these reviews show how townships come to be collectively produced as adaptive and self-sufficient places, rather than as places where urgent and radical infrastructural change is needed (Jones and Sanyal, 2015).

Poor but happy children. Our analysis suggests that the image of the happy child is central to producing the slum of hope in tourists' reviews. Narratives about children were one of the most prominent themes in the data. One hundred and seven of the 417 Langa reviews and 13 of the 35 Imizamo Yethu reviews include references to children. Tourists repeatedly juxtaposed the poor living conditions of informal settlements with descriptions of happy, laughing, singing and playing, and well-cared-for children. Many reviews described visits to schools or day care centres within the townships, commented positively on the services children received there. Thus, on TripAdvisor, townships became places where children could be 'genuinely happy' and thrive. 
Despite of the basic conditions they live, we were amazed to see lots of kids playing on the streets with smiles on their faces as probably you do not see in the mansions that we had passed before. (Imizamo Yethu: Mateo, Argentina)

\section{Don't Just Drive By the Townships!!}

Yes, certainly, the poverty is intense and the living conditions for many are dire. But children play safely outside, something no longer possible in many of our central cities in the US. And when they succeed educationally and economically, most Langans choose to stay-giving children role models and creating the kind of economic diversity that many of our neighborhoods lack. (Langa: Ray, USA)

As is evidenced by Mateo and Ray's narratives above, some reviewers suggested that children in townships, in some ways, live better lives than children living in privileged areas. Reviews like these communicate a sense of nostalgia, as tourists suggest that children in Langa could play safely outside in a way that children in cities in America no longer could. These reviews operate in a context where the material reality is that children in South African townships play far from safety. In addition to living in communities characterised by high levels of violence, children in townships routinely get sick from having to play in and amongst highly contaminated streams of sewerage runoff in streets that results from inadequate, inappropriate, or non-existent sanitation infrastructure. Tourists' nostalgic narratives reflect an othering colonial gaze that collectively feeds into a broader romanticisation of poverty by the western subject who, in the face of increasingly individualist and globalised society, yearns for a sense of communal togetherness and a simpler way of life (Steinbrink, 2012).

Discourses of choice. Ray's review above also reflects the neoliberal discourse of individual choice, freedom and mobility (Bansel, 2007) that flowed steadily across tourists' narratives. Ray states that, 'when they succeed educationally and economically, most Langans choose to stay', thereby constructing the contented resident who lives or remains in the township out of choice rather than constraint. The two reviews that follow also reflect this discourse of choice:

Informative and Emotional Journey - Must Do in Cape Town

I was prepared for the poverty, but I was not prepared for the beauty, joy and hope I saw as the people opened up their homes to us with pride. Nossi made us understand that while there is much room for improvement, these people love their community and wish to remain in that community for a variety of reasons (Langa: Julie336, USA) 


\section{A more holistic view of South Africa}

The community spirit, the desire to remain in the township and improve it, the value on education, on keeping Xhosa traditions alive, of the importance of family (in particular the elderly) and the positivity of all we met despite hardships and extreme poverty will stay with us. (Langa: KateR57, UK)

This neoliberal discourse of unequivocal choice overlooks the complexity of residents' presence in these townships. This choice discourse, with its assumptions of individual freedom and self-determination, disregards the enduring and cyclical way that poverty operates. The choice narrative masks the reality that, 25 years after apartheid, many black South Africans live in spaces that were engineered to control, exploit, and oppress them and that continue to be characterised by overcrowding, high incidence of disease, and the lack of basic sanitation services.

In the excerpt above, Julie336 suggests that residents choose to stay in townships as a way of 'keeping Xhosa traditions alive'. The narrative of choice here simultaneously reflects a colonial gaze which naturalises poverty by producing townships primarily as places of culture and heritage (Iqani, 2016). Julie336 seamlessly confounds township conditions with Xhosa culture, thereby producing (Xhosa) culture as something that cannot exist outside of the township. Conversely, Iqani reminds us that:

Slums are the legacy of history: colonialism, apartheid, neoliberal structural adjustments, and ongoing exploitation of the labour of the poor have produced these places. They are not natural, they did not simply pop up overnight like mushrooms. People are not 'stricken' with poverty; that poverty was produced. (Iqani, 2016: 83)

To summarise, in the first section of our discussion we have demonstrated how tourists collectively produce townships as places of hope on TripAdvisor. In the absence of discourses of despair, townships were constructed as productive spaces, rich in non-material assets, inhabited by happy children and hard-working adults with hope for the future. We show how neoliberal and colonial discourses operate together in these reviews to naturalise poverty and erase inequalities between tourist and slum dweller, and the broader inequalities between global north and south that they represent (Iqani, 2016). In the section that follows we will attend more closely to the question of why township tourists so consistently reproduce these slums of hope discourses in their post-tour accounts - in other words, we explore what these discourse of hope 'do' for tourists. 


\section{2 'Ethical tourism' and the morally superior township tourist}

Tourists who go on township tours engage in a particularly controversial and contested practice which exists within a broader global context where there is increasing criticism of mass tourism and a growing anti-tourism discourse (Frenzel, 2013; Iqani, 2016; McWha et al., 2016; Nisbett, 2017). Given the controversy and stigma around township tourism, it is perhaps unsurprising that discourses of voyeurism, exploitation, and invasiveness were prominent in tourists' reviews. Many tourists used terms like 'poverty tourism', 'cultural exploitation' and 'poverty porn' in their reviews, reflecting their awareness of common controversies and critiques around township tourism. However, these discourses were only employed to argue that their tours were not voyeuristic or intrusive. For example, Ana from Germany gave her review the title: 'No "poverty voyeurism", highly informative, interesting, safe'. We argue that township tourists use TripAdvisor as a space to manage their identities, to explicitly resist and reject the possibility that their tourism had been voyeuristic, exploitative, or intrusive.

We will develop the argument that tourists (by drawing on colonial and neoliberal discourses) produce townships as places of hope to allow them to reframe township tours as a form of ethical tourism. We argue that how a township tourist can define their own tourism practices is contingent upon how the township itself is constructed. In order for the tourist to be ethical, the tour must be ethical. In order for the tour to be ethical, the township must be imagined as a place of hope rather than a place of despair. The following excerpt elucidates our argument:

Hope for the future:

This is not a tour to look at poverty, but to inspire and look ahead. South Africa has a long way to go...Previous trip to Langa 7 years ago, shows that change is slowly taking place (Langa: Andy, USA)

Andy's narrative, entitled 'hope for the future', suggests that when the township is a place of progress and hope, the township tour is 'not a tour to look at poverty'. If the township tour is not to look at poverty, then the township tourist cannot be said to be engaging in the 'poverty porn' or the voyeurism commonly associated with slum tourism. By constructing the township as a place of hope, Andy is able to reimagine himself as an ethical tourist on a tour to 'inspire and look ahead'. In the remainder of this section we will explore how tourists positioned 
themselves as ethical, enlightened, and morally superior tourists in the following ways: by constructing the image of the welcoming resident, by producing the Other township tourist, by reframing the township tour as inherently charitable, as an 'authentic' experience, and as a cultural experience.

Constructing the welcoming township. The image of the friendly and welcoming resident was repeatedly evoked in reviews of both Langa and Imizamo Yethu tours. Similarly, $30 \%$ of the respondents in Rolfes' (2010) study on township tourism in Cape Town remarked on the friendliness of township residents. We found that, rather than appearing haphazardly in the TripAdvisor reviews, the discourse of the friendly and welcoming resident appeared consistently and purposefully. Narratives of friendly residents were often positioned alongside discourses about voyeurism, functioning as a rebuttal against them. Meschkank (2011: 58) makes a similar observation in her research with slum tourists, suggesting that 'doubts concerning the morality of the tour tended to be resolved due to the reception the tour received from the residents'. The excerpts below provide examples of how images of friendly residents were employed to counter discourses of voyeurism, and to resolve anxieties around the moral questionability of the tourist practice they are implicated in.

The locals seemed to accept our presence, something I was concerned about - I didn't want to be a patronising tourist participating in a version of "poverty porn". (Langa: Shane, Australia)

\section{A great experience of real South Africa.}

My fiancée and I really wanted to learn about the history of the townships but I was wary of becoming the rich white-man making a spectacle of people's poverty. My concerns were completely un-founded however ... there was no feeling that we were imposing and people seemed genuinely keen to show us their way of life, especially the woman who welcomed us into her home and seemed embarrassed she had not had time to do her hair. (Imizamo Yethu: MJ25, UK)

Shane's description of the 'locals' who seem to 'accept' his presence, allowed him to distance himself from the position of the 'patronising tourist' and to reject the possibility that his presence on the tour could be participating in 'a version of "poverty porn"'. Similarly, MJ25 (UK) acknowledged the moral dilemmas and power imbalances imbued in township tours, stating that he was initially wary of 'becoming the rich white-man making a spectacle of people's poverty'. He too was able to elide these anxieties tied into his positionality as wealthy 
white man from the global north, by eliciting the image of the welcoming tourist who forms part of the broader discourse of the slum of hope.

Tied into tourists' lack of recognition of their position of power in these encounters, we noted an absence of nuanced interpretations of residents' friendliness within these reviews. For example, MJ25 failed to consider that residents' hospitality did not necessarily mean that their presence had not been intrusive. They stated that there was 'no feeling' that they had been intrusive, despite noting that a woman whose home they visited seemed embarrassed about not having done her hair before they arrived. None of the reviews acknowledged that residents' gestures of friendliness might have been performed, or may have stemmed from anything other than a genuine and uncomplicated happiness about their presence. Therefore, tourists' reviews silenced the power imbalances that exist between poor residents and wealthy tourists from the global north. We argue that the unequivocally happy resident, as part of the broader imaginary of the slum of hope, is essential to the successful construction of the egalitarian non-voyeuristic client.

\section{Constructing the Other township tourist.}

The structure of identification is always constructed through splitting. Splitting between that which one is, and that which is the other. (Hall, 2001: 146)

In a context where conventional tourism is increasingly being understood as gratuitous, exploitative and crass, Frenzel (2016: 8) suggests that 'tourists are often highly uncomfortable in the presence of other tourists, as they appear to be grotesque images of themselves'. Similarly, McWha et al. (2016: 72) suggest that the 'anti-tourist is said to reside in every tourist and surfaces when they desire to be disassociated from the masses'. Research repeatedly shows that tourists involved in forms of alternative or 'ethical' tourism, establish an identity around being different, and morally superior, to tourists who participate in mainstream tourism (Burgold and Rolfes, 2013; Mahrouse, 2011; McWha et al., 2016; Welk, 2004). We found that township tourists also engaged in this same othering of tourists on TripAdvisor. A common strategy they employed was to evoke anti-tourist discourse to acknowledge that township tourists could potentially be voyeuristic, but to provide evidence of why they, and the tour they went on, were different.

Great experience - very educational \& humbling 
After doing a lot of research on Langa township tours, my husband \& I decided to go with Cebisa Tours based largely on all the positive Tripadvisor reviews \& multiple, prompt e-mails exchanged with Cebisa. We also felt it was very important \& more respectful to the Langa residents to walk through the area rather than drive by in big vans or buses, which seemed a little voyeuristic to our tastes. (Langa: Jasper99, USA)

In the review above Jasper99 (USA) construct themselves as the responsible and educated tourists who first thoroughly researched various tour options before carefully choosing the 'respectful' or ethical kind of township tour. They construct their walking tour as fundamentally more respectful than the large 'voyeuristic' bus tours that other township tourists chose. In this way tourists were able to create the Other kind of voyeuristic township tour, and the Other kind of township tourist, on whom the stigma associated with township tourism could be pegged.

The township tour as charity. In line with previous research, we found that tourists deployed discourses of ethical tourism to reframe their township tourism as a moral and ethical practice (Burgold and Rolfes, 2013; Butler, 2010; Iqani, 2016). The assertion that township tours are inherently charitable, and that going on a township tour is in itself a charitable act allowed tourists to position themselves as charitable.

I would recommend a visit to the township to help the community. (Imizamo Yethu: Mia, UK)

Its highly recommended that if you believe in true charity do carry whatever you can to donate here. (Imizamo Yethu: Raghu, India)

Reviews like these took a tone of moral superiority, implying that going on a township tour is 'the right thing to do'. Many reviews contained specific instructions or recommendations for the imagined reader about how they too could be charitable on township tours. The reviews urged the imagined readers to go on a township tour if they too believe in 'true charity'. The decision to go on a township tour thus becomes a decision to be charitable. This directive moralising tone is reflected in Charlotte's narrative below:

\section{Enlightening:}

We were on a tour bus that stopped at this settlement, my family and one other got off. Our tour guide said not many people get off at that stop. It is too easy to go to South Africa, and go to table mountain, camps bay, the rich houses. The nice 
restaurants, and to ignore the poverty that is going on just around the corner. I'd highly suggest taking this tour. The small ticket price goes into bettering the community. Don't ignore the stop, the tour guide says the tours help raise awareness, and it opened my eyes to a lot of things. (Imizamo Yethu: Charlotte, UK)

Charlotte tells the story of two kinds of tourists. The first kind of tourist, like herself, takes the path less travelled and gets off the bus to go on the township tour - a small price to pay to help the community. The Other kind of tourist takes the easy route, and chooses to stay on the bus and 'ignore the poverty'. Through this process of splitting, by evoking both anti-tourist and ethical tourist discourses, Charlotte is able to position herself on a moral high ground in relation to the tourist who comes to Cape Town only to enjoy all the luxuries. We argue that discourses of ethical tourism were deployed by tourists to counter dominant understandings of township tours as immoral and exploitative. Rather than going on a township tour, choosing not to go on a township tour was reframed as the immoral choice. In line with research on alternative and ethical tourism (Huggan, 2002; Mahrouse, 2011; McWha et al., 2016), our research shows that tourists counter the stigma around township tourism by constructing the tours along the lines of ethical consumption on TripAdvisor. In doing so they can distinguish and distance themselves from conventional tourists, positioning themselves as more enlightened and as morally superior.

The authentic experience. Previous research on slum tourism identifies the quest for authenticity as a key motivating factor behind tourists' decisions to go on township tours (Burgold and Rolfes, 2013; Meschkank, 2011; Rolfes, 2010). Many of the reviews, like Charlotte's review above, draw on discourses that emphasise the heterogeneity of the city of Cape Town. Reviewers described the city as a multi-faceted place where wealth and luxury is juxtaposed - as Affan (Turkey) says of Imizamo Yethu, 'Richness and poverty separated with a road'. Some tourists constructed township tours as an opportunity to experience this 'wealth of contrasts' and gain a holistic experience of the city of Cape Town. Other tourists went further to suggest that a township tour is necessary for a holistic and authentic experience of South Africa. For example, Nicky (Israel) says, 'no visit to South Africa is complete without a tour like this', or MJ25's review of Langa that is entitled 'A great experience of real South Africa'. Here, authenticity is constructed as something that can only be obtained through engaging in township tourism. 
Meschkank (2011) goes further to argue that that poverty becomes a necessary condition for the experience of 'authenticity' for tourists from the global north visiting the global south. In support of this argument, many of the reviews we analysed the 'real' South Africa was constructed as something that would be found in the poor townships, while the modern and lavish lifestyles that tourists ordinarily enjoyed while visiting South Africa were deemed unauthentic or contrived. These particular ideas about 'authenticity' reflect a colonial gaze that discursively fixes South Africa outside of urban modernity; it rejects the possibility that (some) people in South may enjoy lifestyles that bear similarity to their own. This mechanism of Othering simultaneously reproduces well-established colonial tropes of Africa as impoverished, backward, and underdeveloped.

Township tours as cultural experiences. Tourists were able to reimagine townships, in line with discourses of hope, as vibrant cultural spaces on TripAdvisor. This allowed them to reframe township tours as informative cultural experiences and explicitly negate claims of voyeurism and exploitation. Reviewers often described tours as 'eye-opening', 'must-do', educational and cultural experiences where tourists could (and should) learn about the history of the township and develop an understanding of the daily lives and culture of the people living there. In doing so, they simultaneously positioned themselves as more 'enlightened', socially conscious, informed, and educated than mainstream tourists who came to South Africa without going on a township tour.

Like many, I wasn't sure if I wanted to see a township because I didn't want to gawk at how poor people lived their daily lives. It seemed intrusive. But this tour was far from that. It was more of a cultural learning experience and I didn't feel uncomfortable at any time on the tour. Go on this tour...it's completely safe and very informative! (Alex: Langa, USA)

A fantastic and important cultural experience that more people should do (Langa: Liam, UK)

I highly recommend Siviwe Tours if you're looking for a real immersion into South African black Township culture and life (GTJ_24: Langa, USA)

The construction of the slum tour as a cultural encounter, or the culturalization of the slum, is not a new phenomenon (Steinbrink, 2012). Steinbrink (2012) traces the construction of the slum as the place of the 'ethno-cultural Other' to the turn of the twentieth century in the USA, 
when there was an in influx of immigrants from Eastern and Southern Europe and from Asia. Steinbrink shows how racism and xenophobia shaped employment opportunities and urban development. This led to segregated immigrant quarters such as 'china town' and 'little Italy', which were characterised by poor living conditions and economic poverty. Much like present day constructions of slums by tourists, Steinbrink shows how these areas became marked as exotic, colourful, charming attractions that were evidence of the diversity of the city, a melting pot of 'cultures':

This notion permitted the tourists to see the living and working conditions of the different immigrant groups as expressions of a 'cultural identity'. To them, the immigrant-quarters dwellers functioned as bearers of their respective cultures. Whatever they did was interpreted as a cultural expression of their 'unalterable nature'. (Steinbrink, 2012: 226-227)

Similarly, our analysis showed that tourists defined the township as an opportunity for 'immersion' into the culture of black township residents. Here we see how the township comes to stand in for culture rather than for urban poverty. Attributing residents' way of life in townships to culture, rather than as shaped by poverty, serves to depoliticise and deproblematise poverty, while simultaneously stigmatising the bearers of those 'cultures' (Steinbrink, 2012). As a caveat, we do not imply that townships are devoid of culture. However, when reviewers redefine their townships as primarily places of culture, they silence the intersections between culture, race, and poverty, and the ways in which residents' lives are shaped, constrained and transformed by poverty.

To provide another example of the culturalization of the slum on TripAdvisor, in the excerpt that follows Sam attributes adult residents asking for the sweets that she was handing out to children as a 'cultural difference':

I did bring some candy to give to children, which helped us to meet a lot of cute kids as we walked around. (Apparently strangers handing out candy to your children is not nearly as creepy as it might be at home.) Strangely, many adults also asked for candy when they saw me passing it out to kids, which was an interesting cultural difference... Even though some of them have managed to become educated and relatively well-off, they haven't left Langa Township, but rather have built upper class homes within the township, to keep connected with their culture and community. (Langa: Sam, USA).

Sam does not consider that the act of asking for sweets might be an indication of poverty rather than a reflection of 'cultural difference'. Sam's use of the discourse of 'culture' within the township sheds further light on the theme of choice presented in the first section of the 
paper, where we discussed how tourists positioned residents as choosing to stay in townships to preserve their culture. On TripAdvisor, tourists like Sam reproduced the early twentieth century colonial discourses which construct the slum as an inevitable manifestation of culture rather than as a result of poverty and centuries of systematic structural inequality (Steinbrink, 2012). Sam's narrative reinforces understandings of inevitability of the township - the idea that the township would continue to exist in the absence of poverty because it is primarily a cultural context rather than a manifestation of social inequality. When the slum becomes a natural cultural context, the slum tourist can imagine themselves as engaging in an enlightening cultural exchange rather than in a form of voyeuristic 'poverty porn'.

\section{Concluding remarks: towards complex representations of urban poverty in the global south}

Our analysis has shown that tourists on TripAdvisor collectively construct townships as places of hope, and that these discourses feed into broader understandings of urban poverty in the global south. That tourists construct slums as places of hope and progress in their post-tour accounts supports previous online (Iqani, 2016; Nisbett, 2017) and offline (Meschkank, 2011; Rolfes, 2010) research. Our paper adds to existing knowledge on slum tourism by providing deeper insight into how townships come to be discursively produced as places of hope, and why it may be that tourists consistently represent slums in this way despite the visible material and infrastructural deficits that define urban slums.

The marked silences within our data show that slums of hope are produced in the absence of discourses of despair. This finding supports the assertion that slums of hope and slums of despair operate as dichotomies (Nuissl and Heinrichs, 2013). We show that slums of hope discourses are deployed by tourists to subvert common representations of slums as places of despair. This dichotomy leaves no room for complex and nuanced representations that can accommodate the notion of slums as simultaneously places of hope and despair. Given how deeply politicised issues of sanitation in townships have been in South Africa over the past decade (See McFarlane and Silver, 2017; Robins, 2014a, 2014b), we were particularly struck by the silences around water and sanitation infrastructure in tourists' reviews. The data suggests that, for townships to be imagined as places of hope, they cannot be places where streets are filled with faeces - to talk about townships as places of hope is to be silent about 
their lack of toilets and running water. By silencing these issues, slums of hope discourses produce the (illusionary) sanitised slum.

Our paper demonstrates how both neoliberal and colonial discourses are deployed by tourists on TripAdvisor to produce townships as places of hope and progress. Perhaps our most central finding is that these two discourses are deployed and operate together. We have presented excerpts from TripAdvisor reviews that show how together these discourses function to represent townships in ways that naturalise poverty and conceal the inequalities between tourist and slum dweller as well as the broader inequalities between the global north and south that they come to represent (Iqani, 2016).

In attending to the question of what discourses of hope 'do' for tourists, we argue that constructing townships as places of hope is a necessary condition for tourists to position themselves within discourses of ethical tourism (Mahrouse, 2011). Tourists' accounts of going on township tours occur within a moment when a dominant discourse on township tourism positions them as exploitative voyeurs. Discourses of hope and images of content and welcoming residents provides a counter-discourse that allows tourists to reframe tours as socially conscious cultural encounters. Through enlisting neoliberal discourses of choice, resilience, adaptability and self-help, delivered through an othering colonial gaze that produces the township as a manifestation and the bearer of African culture, the potentially stigmatising act of going on a township tour can be reframed an authentic cultural exchange. To this end, we argue that slums of hope becomes a counter-discourse, an identity management tool, that allows tourists to resist claims of voyeurism and exploitation and to construct themselves as socially conscious, enlightened and as morally superior to tourists who choose not to engage in township tours.

Our findings suggest that tourists' reviews on TripAdvisor can contribute to what FreireMedeiros (2009: 587) calls a 'new politics of visibility' for townships that challenges the prevailing stigmas around urban poverty in the global south, producing townships as places that matter, places that other people should care about and thus invest in (Dickson, 2012; Frenzel, 2016). However, our findings suggest that slum tourists' reviews simultaneously contribute to an older politics of invisibility. Our research shows how neoliberal and colonial discourses produced within these TripAdvisor reviews operate together to silence the enduring and oppressive nature of poverty and inequality. The question of urban sanitation 
in South Africa is always already political, and therefore the silences around sanitation highlighted by our analysis are political too (McFarlane and Silver, 2017). The need for radical social and infrastructural change in these townships are made invisible in tourists' reviews. The infrastructural deficits in townships, and the symbolic and material hopelessness and stagnation that they maintain, must be politicised rather than silenced in order to summon the local and international pressure necessary for 'making the state responsive to the needs of the urban poor' (Jones and Sanyal, 2015; Robins, 2014: 107).

While this paper is concerned with tourists' online representations of townships, tourists are not the only ones who collectively produce representations of urban poverty. Our findings bear relevance to anyone doing work within or about areas of urban poverty in the global south. Social scientists such as ourselves, along with natural scientists, policy makers, development workers, and activists must all be cognisant of how we might reproduce these 'slums of hope' and 'slums of despair' discourses as binaries in and though our own research and writing. This paper highlights the importance of working towards producing nuanced representations of townships as complex places that are characterised by both hope and despair at the same time (Jones and Sanyal, 2015). Representations of townships should acknowledge residents' assets and excellence, thereby resisting stigmatising colonial understandings of Black Africans as helpless, while also foregrounding how residents live within the oppressive constraints inherent in enduring systems of inequality. 


\section{References}

Bansel P (2007) Subjects of choice and lifelong learning. International Journal of Qualitative Studies in Education 20(3): 283-300. DOI: 10.1080/09518390701281884.

Boonzaier F (2017) The Life and death of Anene Booysen: Colonial discourse, gender-based violence and media representations. South African Journal of Psychology 47(4): 470481. DOI: $10.1177 / 0081246317737916$.

Braun V and Clarke V (2006) Using thematic analysis in psychology. Qualitative Research in Psychology: 77-101.

Braun V, Clarke V, Hayfield N, et al. (2019) Thematic Analysis. In: Liamputtong P (ed.) Handbook of Research Methods in Health Social Sciences. Singapore: Springer Singapore, pp. 843-860. DOI: 10.1007/978-981-10-5251-4_103.

Burgold J and Rolfes M (2013) Of voyeuristic safari tours and responsible tourism with educational value: Observing moral communication in slum and township tourism in Cape Town and Mumbai. DIE ERDE - Journal of the Geographical Society of Berlin 144(2): 161-174.

Butler SR (2010) Should I stay or should I go? Negotiating township tours in post-apartheid South Africa. Journal of Tourism and Cultural Change 8(1-2): 15-29. DOI: 10.1080/14766821003777756.

Colditz JB, Chu K-H, Emery SL, et al. (2018) Toward real-time infoveillance of Twitter health messages. American Journal of Public Health 108(8): 1009-1014. DOI: 10.2105/AJPH.2018.304497.

Davis M (2006) Planet of Slums. London: Verso.

De Satgé R and Watson V (2018) Urban Planning in the Global South: Conflicting Rationalities in Contested Urban Space. Cape Town, South Africa: Springer.

Dickson JL (2012) Revisiting 'township tourism': multiple mobilities and the reterritorialisation of township spaces in Cape Town, South Africa. Anthropology Southern Africa 35(1-2): 31-39. DOI: 10.1080/23323256.2012.11500021.

Diekmann A and Hannam K (2012) Touristic mobilities in India's slum spaces. Annals of Tourism Research 39(3): 1315-1336. DOI: 10.1016/j.annals.2012.02.005.

Dyson P (2012) Slum Tourism: Representing and Interpreting 'Reality' in Dharavi, Mumbai. Tourism Geographies 14(2): 254-274. DOI: 10.1080/14616688.2011.609900.

Feltwell T, Vines J, Salt K, et al. (2017) Counter-discourse activism on social media: The case of challenging "poverty porn" television. Computer Supported Cooperative Work (CSCW) 26(3): 345-385. DOI: 10.1007/s10606-017-9275-z. 
Freire-Medeiros B (2009) The favela and its touristic transits. Geoforum 40(4): 580-588. DOI: 10.1016/j.geoforum.2008.10.007.

Frenzel F (2013) Slum tourism in the context of the tourism and poverty (relief) debate. DIE ERDE - Journal of the Geographical Society of Berlin 144(2): 117-128.

Frenzel F (2016) Slumming It: The Tourist Valorization of Urban Poverty. London: Zed Books Ltd.

Gibson L, Engelbrecht J and Rush D (2019) Detecting historic informal settlement fires with sentinel 1 and 2 satellite data - Two case studies in Cape Town. Fire Safety Journal 108: 102828. DOI: 10.1016/j.firesaf.2019.102828.

Hall S (2001) Old and new identities, old and new ethnicities. In: Back L and Solomos J (eds) Theories of Race and Racism: A Reader. London: Psychology Press, pp. 144-154.

Huggan G (2002) The Postcolonial Exotic: Marketing the Margins. London: Routledge.

Huysamen M and Boonzaier F (2018) "Out of Africa": Racist discourse in men's talk on sex work. Psychology in Society 57: 58-80. DOI: https://www.pins.org.za/latest.php.

Iqani M (2016) Slum tourism and the consumption of poverty in TripAdvisor reviews: The cases of Langa, Dharavi and Santa Marta. In: Consumption, Media and the Global South: Aspiration Contested. New York: Palgrave Macmillan, pp. 51-86.

Jones GA and Sanyal R (2015) Spectacle and suffering: The Mumbai slum as a worlded space. Geoforum 65: 431-439. DOI: 10.1016/j.geoforum.2015.02.008.

Jovicic D (2016) Cultural tourism in the context of relations between mass and alternative tourism. Current Issues in Tourism 19(6): 605-612. DOI:

10.1080/13683500.2014.932759.

Kahanji C, Walls RS and Cicione A (2019) Fire spread analysis for the 2017 Imizamo Yethu informal settlement conflagration in South Africa. International Journal of Disaster Risk Reduction: 101146. DOI: 10.1016/j.ijdrr.2019.101146.

Koven S (2006) Slumming: Sexual and Social Politics in Victorian London. London: Princeton University Press.

Lugones M (2010) Toward a decolonial feminism. Hypatia 25(4): 742-759.

Mahrouse G (2011) Feel-good tourism: An ethical option for socially-conscious Westerners? I ACME: An International Journal for Critical Geographies. Acme: An International EJournal for Critical Geographies 10(3): 372-391.

McFarlane C and Silver J (2017) The poolitical city: "Seeing Sanitation" and making the urban political in Cape Town. Antipode 49(1): 125-148. DOI: 10.1111/anti.12264. 
McWha MR, Frost W, Laing J, et al. (2016) Writing for the anti-tourist? Imagining the contemporary travel magazine reader as an authentic experience seeker. Current Issues in Tourism 19(1): 85-99. DOI: 10.1080/13683500.2015.1013525.

Meschkank J (2011) Investigations into slum tourism in Mumbai: poverty tourism and the tensions between different constructions of reality. GeoJournal 76(1): 47-62. DOI: 10.1007/s10708-010-9401-7.

Nisbett M (2017) Empowering the empowered? Slum tourism and the depoliticization of poverty. Geoforum 85: 37-45. DOI: 10.1016/j.geoforum.2017.07.007.

NuissI H and Heinrichs D (2013) Slums: Perspectives on the definition, the appraisal and the management of an urban phenomenon. DIE ERDE - Journal of the Geographical Society of Berlin 144(2): 105-116.

Owusu G, Agyei-Mensah S and Lund R (2008) Slums of hope and slums of despair: Mobility and livelihoods in Nima, Accra. Geografisk Tidsskrif 62(3): 180-190. DOI: DOI: 10.1080/00291950802335798.

Parker I (1992) Discourse Dynamics: Critical Analysis for Individual and Social Psychology. London: Routledge.

Parker I (2004) Discourse Analysis. In: Flick U, Kardorff E, and Stein I (eds) A Companion to Qualitative Research. London: SAGE, pp. 308-312.

Privitera D (2015) Tourist Valorisation of Urban Poverty: an Empirical Study on the Web. Urban Forum 26(4): 373-390. DOI: 10.1007/s12132-015-9259-3.

Reed J (2012) The disastrous and politically debased dubject of resilience. Development Dialogue 58: 67-80.

Robins S (2014) Slow Activism in fast times: Reflections on the politics of media spectacles after apartheid. Journal of Southern African Studies 40(1): 91-110. DOI: 10.1080/03057070.2014.889517.

Rolfes M (2010) Poverty tourism: theoretical reflections and empirical findings regarding an extraordinary form of tourism. GeoJournal 75(5): 421-442. DOI: 10.1007/s10708009-9311-8.

Rutherford A (2018) Feminism, psychology, and the gendering of neoliberal subjectivity: From critique to disruption. Theory \& Psychology 28(5): 619-644. DOI: 10.1177/0959354318797194.

Steinbrink M (2012) 'We did the slum!' - Urban poverty tourism in historical perspective. Tourism Geographies 14(2): 213-234. DOI: 10.1080/14616688.2012.633216.

Stokes CJ (1962) A theory of slums. Land Economics 38(3): 187-197. DOI: 10.2307/3144581.

Taylor GW and Ussher JM (2001) Making Sense of S\&M: A Discourse Analytic Account. Sexualities 4(3): 293-314. DOI: 10.1177/136346001004003002. 
Walker G, Cass N, Burningham K, et al. (2010) Renewable energy and sociotechnical change: Imagined subjectivities of 'the public' and their Implications. Environment and Planning A: Economy and Space 42(4): 931-947. DOI: 10.1068/a41400.

Welk P (2004) The beaten track: anti-tourism as an element of backpacker identity construction. In: Richards G and Wilson JC (eds) The Global Nomad: Backpacker Travel in Theory and Practice. Clavedon: Channel View Publications, pp. 77-91.

Wetherell M (2007) A step too far: Discursive psychology, linguistic ethnography and questions of identity. Journal of Sociolinguistics 11(5): 661-681. DOI: 10.1111/j.14679841.2007.00345.x.

Williams C (2008) Ghettourism and voyeurism, or challenging stereotypes and raising consciousness? Literary and non-literary forays into the favelas of Rio de Janeiro. Bulletin of Latin American Research 27(4): 483-500. DOI: 10.1111/j.14709856.2008.00280.x. 